\title{
Institutionalization as Discrimination: How Medicaid Waivers, the ADA, and $§ 1983$ Fail $^{*}$
}

\section{INTRODUCTION}

In February 1999, I became employed with Cottonwood, Inc., a service provider for adults with developmental disabilities. I worked with women who lived together in a group home. I was responsible for assisting these women in living their lives as they saw fit. As my job title changed over the years, my responsibility remained primarily the same: helping someone with a developmental disability live the way they wanted. In addition to a greater understanding of this role, I also became aware of the structure in which this role exists. Many of the people I worked with were eligible for Medicaid services, and received these services through one of Kansas's home and community-based waiver programs.

Eventually, I left Cottonwood to work at Kansas Advocacy and Protective Services, Inc. (now the Disability Rights Center of Kansas). There, I discovered that an extensive waiting list for home and community-based services inhibits access to these services. I also discovered that there were a variety of waiver programs, and some difficulty in not only qualifying for the programs, but in getting off the waiting lists and actually receiving the program services.

Consider the following scenario: Jane Smith has a disability which qualifies her for institutional care, such as placement in a nursing home or state hospital. After spending time in this institution, a medical professional determines that with enough staff support-attendants to assist with daily living needs - Jane could be in a community setting like a group home or even her own apartment. Jane has a right to services in the most integrated setting. Jane's family helps her locate an appropriate place nearby which can accommodate Jane. Unfortunately, there is not an open space on the Medicaid waiver program to fund Jane's placement. Jane cannot work because her disability is severe, and there is no other way to raise the funds necessary to support her in a community setting. What exactly can Jane do in order to move out of the institution and into 
a community-living situation? This Comment will revisit Jane's dilemma throughout its analysis.

Under the New Freedom Initiative, ${ }^{1}$ the federal government is pouring money into state Medicaid programs to facilitate the movement of Americans with disabilities from institutions into community settings. ${ }^{2}$ Steps must be taken to ensure those individuals' rights throughout the process. The current $\S 1983$ Medicaid jurisprudence offers insight into the present civil rights dilemma arising from these questions: How can individuals enforce their Americans with Disabilities Act (ADA) right to services in the most integrated setting while receiving Medicaid-provided health care without imposing undue financial hardship on individual states? Will Medicaid waiver programs and the courts erode protections given to people with disabilities by the ADA? How do the ADA and $\S$ 1983 Medicaid litigation work incongruously in ultimate service provision?

While the circuits continue to decide and argue over which provisions of Medicaid confer rights to individuals, states continue to change their Medicaid plans implementing the federal statute. Most states use $\S 1396 \mathrm{n}(\mathrm{c})$ waivers to provide home and community-based services. A growing number of states are also implementing demonstration projects using $\S 1315$ waivers. The waiver programs and demonstration projects allow states greater flexibility in reaching the goals of Medicaid. However, this flexibility also changes a number of requirements-including eligibility requirements-for Medicaid recipients. In some cases, this might mean an increased recipient pool. In other cases, this might mean a limited service in a single portion of the state. Regardless of the actual impact of the program or demonstration project, there are additional legal impacts for Medicaid recipients.

This Comment argues that as states seek cost-effective ways to implement Medicaid provisions and provide services, states also endanger the fragile legal right individuals have to a private cause of action under $\S 1983$ to enforce their access to prompt health care services

* Julia Gilmore Gaughan. J.D. candidate 2008, University of Kansas School of Law; B.A. 2001, University of Kansas. I would like to thank Professors Elizabeth Weeks and Stephen McAllister for their review and assistance with this Comment. I would also like to thank my husband Mike and our son Kiernan for their love and support.

1. Exec. Order No. 13,217, 66 Fed. Reg. 33,155 (June 18, 2001), available at http://www. whitehouse.gov/news/releases/2001/06/20010619.html.

2. Ron Knox, U.S. to Move Elderly, Disabled from Institutions, LAWRENCE JOURNAL-WORLD (Kan.), Oct. 9, 2006, at B1; Medical News Today, States Get Federal Grants to Help People With Disabilities Live in the Community, USA, Sept. 16, 2006, http://www.medicalnewstoday.com/ articles/52045.php (last visited Dec. 20, 2007). 
under Medicaid. This erosion of rights combines with the decision in Olmstead v. L.C. ex rel. Zimring ${ }^{3}$ in a surprising way, creating less protection for people with disabilities from ADA-prohibited discrimination. While states must be permitted flexibility to meet the growing needs and costs of Medicaid, additional steps must be taken to ensure both the entitlement nature of Medicaid for Americans with disabilities and the right to receive services of public accommodation in the most integrated setting under the ADA.

Part II of this Comment outlines the Medicaid program generally and the waiver programs in detail. Then, relevant portions of the ADA are discussed, followed by an extensive look at Olmstead, a landmark disability rights decision. Part II culminates with a review of the subsequent decisions upholding Olmstead, and a discussion of the interplay between these decisions and access to community-based Medicaid services.

In Part III, this Comment outlines $\S 1983$ jurisprudence as it relates to the enforcement of Medicaid provisions. After briefly discussing the test set forth in Blessing v. Freestone and the initial Wilder v. Virginia Hospital Association decision finding Medicaid enforceable with $\S 1983$, Part III ends in an examination of circuit court decisions covering Medicaid both outside and within a waiver program context. In Part IV, this Comment analyzes the Olmstead and $\S 1983$ Medicaid issues together in light of new attempts to move individuals out of institutions. Both Supremacy Clause litigation and policy initiatives will be reviewed in their capacity to protect the civil rights of people with disabilities in the face of further Medicaid devolution.

\section{HEALTH CARE IN THE Most InTEGRATED SETting FOR AMERICANS WITH DISABILITIES}

Since its enactment, Medicaid has been amended and developed extensively to meet a variety of needs and assuage political desires and fears. ${ }^{4} \quad$ Medicaid's statutory structure has remained relatively unchanged, ${ }^{5}$ but interpretation of Medicaid's structure has grown

3. 527 U.S. 581 (1999).

4. See generally KaISer COMM'N ON Medicaid AND the Uninsured, MEdicaid: A TiMELINE OF KEY DEVELOPMENTS, http://www.kff.org/Medicaid/Medicaid_timeline.cfm (last visited Dec. 20, 2007).

5. Sara Rosenbaum, Medicaid at Forty: Revisiting Structure and Meaning in a Post-Deficit Reduction Act Era, 9 J. HeAlth CARE L. \& POL'Y 5, 11 (2006). 
increasingly narrow. ${ }^{6}$ Although the ADA was enacted twenty-five years after Medicaid, the ADA's requirements uniquely interact with Medicaid - something the courts have been loathe to address.

\section{A. An Overview of Medicaid and Medicaid Waiver Programs}

Medicaid is a program administered by the states and funded jointly by the states and the federal government. ${ }^{7}$ Over fifty-five million people are enrolled in Medicaid; approximately fourteen percent of these enrollees have disabilities. ${ }^{8}$ While Congress created Medicaid at the same time it created Medicare, the nature of the "entitlement" to Medicaid is less clear than the entitlement to Medicare. ${ }^{9}$ Total Medicaid expenditures "will exceed $\$ 300$ billion" in 2006. ${ }^{10}$ Over one-third of these Medicaid dollars are spent on long-term care services: "services for both elderly and non-elderly persons in institutional settings and in home and community-based setting[s]."11 Looking at both general state plan requirements and the waiver programs states use to provide long-term care provides background for the present legal conundrum.

\section{State Plan Requirements}

In order for states to receive federal Medicaid dollars, each state must submit a state plan for medical assistance which meets numerous requirements. ${ }^{12}$ States have "been permitted a great deal of discretion as to the populations that they cover" and "enjoy a great deal of latitude as to which benefits they cover" with their individual programs. ${ }^{13}$ The most applicable of these state plan requirements to this Comment are found in

6. See id. at 24 ("[T] he right to seek individual redress for violation of statutory obligations is increasingly confined to selected program elements.").

7. Kaiser COMm'N On Medicaid and the Uninsured, Low Medicaid Spending Growth Amid Rebounding State Revenues: Results from a 50-State Medicaid Budget Survey STATE FISCAL YEARS 2006 AND 200713 (2006), available at http://www.kff.org/medicaid/upload/ 7569.pdf [hereinafter 2006 KFF Medicaid State Survey].

8. Id. at 11 .

9. See Timothy Stoltzfus Jost, Disentitlement? The Threats Facing Our Public Health-CARe Programs AND a Rights-Based Response 30-34 (2003) (discussing the entitlement language of Medicare versus the absence of entitlement language in the Medicaid statute).

10. 2006 KFF Medicaid State Survey, supra note 7, at 13.

11. Id. at 11

12. 42 U.S.C. $§ 1396 a(a)(2000)$.

13. Jost, supra note 9 , at 163 . 
$\S \S \quad 1396 a(a)(1), \quad 1396 a(a)(8), \quad 1396 a(a)(10)(B), \quad 1396 a(a)(17), \quad$ and 1396a(a)(30).

Section 1396a(a)(1), the Statewideness Provision, ${ }^{14}$ requires the state plan to be effective throughout the state. ${ }^{15}$ Section 1396a(a)(8), the Reasonable Promptness Provision, ${ }^{16}$ requires that eligibility determinations and medical assistance be provided with reasonable promptness. ${ }^{17}$ Section 1396a(a)(10)(B), the Quality of Care Provision, ${ }^{18}$ requires that medical assistance provided under the state plan "shall not be less in amount, duration, or scope than the medical assistance made available to any other such individual."19 Section 1396a(a)(17), the Reasonable Standards Provision, requires states to provide reasonable standards for use in determining individual Medicaid eligibility and the extent that individuals can receive medical assistance under the program. $^{20}$ Section 1396a(a)(30)(A), the Equal Access Provision, ${ }^{21}$ requires that the payment for medical assistance be enough to guarantee provider availability to Medicaid recipients equal to that available to the general population. ${ }^{22}$

"Medical assistance" is discussed throughout each of these provisions and has a particularly important meaning in Medicaid litigation. The Act defines medical assistance to mean "payment of part or all of the cost of the following care and services" for eligible individuals. $^{23}$ The majority of courts specifically hold that this definition of medical assistance includes only the "payment," not the "provision" of medical services. ${ }^{24}$

14. See Equal Access for El Paso, Inc. v. Hawkins, 428 F. Supp. 2d 585, 619 (W.D. Tex. 2006) (terming $§ 1396 \mathrm{a}(\mathrm{a})(1)$ the "Statewideness Provision" in order to clarify discussion of that specific subsection), rev'd and remanded, No. 06-50599, 2007 WL 4295380 (5th Cir. Dec. 10, 2007).

15. 42 U.S.C. $\$ 1396 a(a)(1)$

16. See Equal Access, 428 F. Supp. 2d at 620 (terming $\S 1396 a(a)(8)$ the "Reasonable Promptness Provision").

17. 42 U.S.C. $\S 1396 a(a)(8)$

18. See Equal Access, 428 F. Supp. 2d at 614 (terming $§ 1396 a(a)(10)(B)$ the "Quality of Care Provision").

19. 42 U.S.C. $\$ 1396 a(a)(10)(B)$

20. Id. § $1396 \mathrm{a}(\mathrm{a})(17)$

21. See Equal Access, 428 F. Supp. 2d at 611 (terming § 1396a(a)(30)(A) the "Equal Access Provision").

22. 42 U.S.C. $§ 1396 a(a)(30)(A)$.

23. Id. $\S 1396 \mathrm{~d}(\mathrm{a})$.

24. Mandy R. v. Owens, 464 F.3d 1139, 1143 (10th Cir. 2006); Westside Mothers v. Olszewski, 454 F.3d 532, 540 (6th Cir. 2006). One commentator has proposed promulgation of a new medical assistance definition focusing on provision as opposed to payment of services for the "fee-for-service" Medicaid recipients. Kenneth R. Wiggins, Note, Medicaid and the Enforceable Right to Receive Medical Assistance: The Need for a Definition of "Medical Assistance," 47 WM. \& MARY L. REV. 1487, 1508-10 (2006). 


\section{The Waiver Programs}

Generally, Medicaid operates like a typical health insurance program - once services have been provided, the provider is reimbursed under a fee schedule ("fee-for-service"). However, for beneficiaries with complex medical needs, this structure can be cumbersome and costprohibitive. Congress first established the waiver programs with the enactment of $\S 1396 \mathrm{n}(\mathrm{c})$ in $1981 .^{25}$ While only six states operated waiver programs during the first year, ${ }^{26}$ the availability of home and community-based services represented a move from institutional care toward the independent living model of care for people with disabilities. $^{27}$ The primary types of waiver authority discussed here (HCBS and Demonstration Project waivers) are granted within the discretion of the Secretary of Health and Human Services. ${ }^{28}$ Both of these waiver programs require budget neutrality: that is, the federal cost of Medicaid for a particular state under a waiver program cannot exceed the cost of Medicaid without the waiver program in that state. ${ }^{29}$ To achieve this, states apply for waiver programs to cover a certain number of individuals and fill these slots as space (and funding) becomes available. Until space is available, eligible individuals remain on waiting lists.

\section{a. HCBS Waivers}

Home and community-based services waivers (HCBS waivers), found in $\S 1396$ n(c), allow for the provision of medical assistance to

\footnotetext{
25. Andrew I. Batavia, A Right to Personal Assistance Services: "Most Integrated Setting Appropriate” Requirements and the Independent Living Model of Long-Term Care, 27 AM. J.L. \& MED. 17, 24 (2001).

26. U.S. Gen. Accounting OfFice, Long-Term Care: Federal Oversight of Growing MedicAid Home AND COMMUnity-BASEd WAivers SHOUld Be STRENGTHened 11 (2003), available at http://www.gao.gov/new.items/d03576.pdf [hereinafter 2003 GAO HCBS Oversight Report].

27. Batavia, supra note 25 , at 24 . This move was particularly important considering the struggle the disability rights movement had faced with getting the regulatory framework of $\S 504$ of the 1973 Rehabilitation Act signed into effect. See JosePH P. Shapiro, No Pity: PeOPLE WITH Disabilities Forging a New Civil Rights Movement 64-70 (1993) (describing the San Francisco protests organized by disability rights activists, which ultimately led to the signing of the Rehabilitation Act's regulatory framework four years after its passage).

28. 42 U.S.C. $\S 1396 n(c)$ and $\S 1315$.

29. ROBIN RUDOWITZ \& ANDY SCHNEIDER, KAISER COMM'N ON MEDICAID AND THE Uninsured, THE Nuts AND Bolts of MAKING MedicAid Policy CHANGES: AN OVERVIEW AND A LOOK AT THE DEFICIT REDUCTION ACT 10 (2006), available at http://www.kff.org/medicaid/upload/ 7550.pdf.
} 
individuals, who would otherwise be institutionalized, in the privacy of their own home or some other community environment. ${ }^{30}$ They are "designed to allow states to experiment with methods of care, or to provide care on a targeted basis, without adhering to the strict mandates of the Medicaid system." "31 HCBS waivers specifically allow states to waive the Statewideness and the Quality of Care Provisions. ${ }^{32}$ Furthermore, these waivers allow states to overlook certain income and resource rules ${ }^{33}$ and allow states to limit the recipients of services under the waiver program. ${ }^{34}$ In ten years, HCBS waivers "grew from 5 percent of all Medicaid long-term care spending in fiscal year 1991 to 19 percent in fiscal year 2001." ${ }^{35}$ Now, over 250 HCBS waiver programs exist. ${ }^{36}$ These waivers "often represent less expensive and more comprehensive alternatives to institutional care." 37 Often, the type of care an individual requires does not need to be provided by a licensed health care professional, but alternatively can be provided by someone the individual chooses and trains to care for his or her unique needs.

\section{b. Demonstration Project Waivers}

Another type of waiver is the Demonstration Project waiver found in $\S 1315 .{ }^{38}$ Unlike the limited "waived" provisions of HCBS waivers, $\S$ 1315 allows the Secretary of Health and Human Services to approve projects that do not comply with any of the provisions of the State Plan requirements located in $\S 1396$ a "to the extent and for the period he finds necessary to enable such State or States to carry out such project." 39 In 2001, the Bush administration began emphasizing Demonstration Project waivers through the Health Insurance Flexibility and Accountability

30. 42 U.S.C. $\S 1396 \mathrm{n}(\mathrm{c})(1)$. These waivers are sometimes referred to as 1915 (c) waivers, but will be referred to generally as HCBS waivers in this Comment.

31. Bryson v. Shumway, 308 F.3d 79, 82 (1st Cir. 2002).

32. 42 U.S.C. $\S 1396 n(c)(3)$.

33. Id.

34. Id. $\S 1396 \mathrm{n}(\mathrm{c})(4)(\mathrm{A})$.

35. 2003 GAO HCBS Oversight Report, supra note 26, at 3.

36. CTRS. FOR MEDICARE AND MEDICAID SERVS., MEDICAID WAIVERS AND DEMONSTRATIONS LIST, http://www.cms.hhs.gov/MedicaidStWaivProgDemoPGI/MWDL/list.asp (last visited Dec. 20, 2007) [hereinafter CMS Waiver Program List] (containing a complete list of current Medicaid waiver and demonstration projects).

37. Jane Perkins \& Randolph T. Boyle, Addressing Long Waits for Home and CommunityBased Care Through Medicaid and the ADA, 45 ST. LouIS U. L.J. 117, 140 (2001).

38. These waivers are sometimes referred to as 1115 waivers but will be referred to as Demonstration Project waivers in this Comment.

39. 42 U.S.C. $\S 1315(a)(1)$. 
Initiative (HIFA). ${ }^{40}$ There are currently over 130 Demonstration Project waivers in use. ${ }^{41}$ While previous reports indicated an increasing interest by the states to use these waivers, newer reports show slowed growth in this area due to the Deficit Reduction Act of $2005 .^{42}$ The Deficit Reduction Act (DRA) allows for a number of changes in state plans which previously required waivers but now only require an amendment to the state plan. ${ }^{43}$

\section{c. Other Waiver Programs}

The DRA implemented two additional waiver programs: Health Opportunity Accounts and Money Follows the Person. ${ }^{44}$ The impact of the DRA generally, and Money Follows the Person in particular, will be discussed more thoroughly in Part IV.A-B. However, it is important to note that both of the DRA waivers differ from the HCBS and Demonstration Project waivers in that they do not require budget neutrality while offering the same freedom from regulation as Demonstration Project waivers. ${ }^{45}$

\section{B. The Americans with Disabilities Act and Olmstead}

Even as Congress recognized that cost-saving in the administration of Medicaid accompanied greater individual rights, more work was needed to secure the civil rights of individuals with disabilities.

40. JosT, supra note 9 , at 171.

41. See CMS Waiver Program List, supra note 36 (select "show only items containing the following word" and enter " 1115 " for a complete list of current Medicaid waiver and demonstration projects). For a general critique of Demonstration Project waivers, see Jonathan R. Bolton, Note, The Case of the Disappearing Statute: A Legal and Policy Critique of the Use of Section 1115 Waivers to Restructure the Medicaid Program, 37 COLuM. J.L. \& Soc. ProbS. 91 (2003).

42. Pub. L. No. 109-171, 120 Stat. 4 (2006).

43. 2006 KFF Medicaid State Survey, supra note 7, at 47-48. The impacts of the DRA on access to alternatives to institutional care will be discussed more thoroughly in Part IV.B.

44. Rudowitz \& SCHNEIDER, supra note 29 , at 13 . In addition to the HCBS and Demonstration Project waivers and the DRA waiver programs, waivers exist under $\S 1396 \mathrm{n}(\mathrm{b})$. This class of waivers can be used to promote cost-effectiveness and efficiency and allows states to waive a variety of provisions of the State Plan requirements. However, these waivers are fairly similar to HCBS waivers and, more importantly, have not been analyzed under $\S 1983$ or in comparison with the ADA. Thus a review of these waivers would not be useful in evaluating the waiver programs' impact on individual rights.

45. RUDOWITZ \& SCHNEIDER, supra note 29 , at 13. 


\section{The Americans with Disabilities Act}

The Americans with Disabilities $\mathrm{Act}^{46}$ prohibits discrimination against people with disabilities in a number of ways. Of importance here is the prohibition of discrimination by public entities: "Subject to the provisions of this subchapter, no qualified individual with a disability shall, by reason of such disability, be excluded from participation in or be denied the benefits of the services, programs, or activities of a public entity, or be subjected to discrimination by any such entity." ${ }^{, 47}$ The enacting regulations further clarify that public entities must "administer services, programs, and activities in the most integrated setting appropriate to the needs of qualified individuals with disabilities." 48 When states administer their Medicaid programs, according to the ADA, the states have an obligation not to discriminate against qualified individuals with disabilities.

The Act defines a "qualified individual with a disability" as: "an individual with a disability who, with or without reasonable modifications to rules, policies, or practices... meets the essential eligibility requirements for the receipt of services or the participation in programs or activities provided by a public entity." ${ }^{49}$ Disability means "a physical or mental impairment that substantially limits one or more of the major life activities of such individual."50 Thus, Medicaid should serve its eligible participants whose impairment "substantially limits one or more... major life activities" in "the most integrated setting appropriate."

With the ADA, Congress recognized that people with disabilities had been historically isolated and segregated, and "such forms of discrimination against individuals with disabilities continue to be a serious and pervasive social problem." ${ }^{\text {, }}$ This language lays the foundation to view the "most integrated setting" requirement as a way to move past a specific form of discrimination faced by people with disabilities.

46. 42 U.S.C. $\$ \S 12101$ to 12300 (2000).

47. Id. $\S 12132$. Section 504 of the Rehabilitation Act also prohibits discrimination against people with disabilities by any group receiving federal funding. 29 U.S.C. $\S 794$ (2000). While additional time could be spent on this topic, the $\S 504$ analysis would be similar to the ADA analysis in its present application and will not be discussed in this Comment.

48. 28 C.F.R. § 35.130(d) (2006). Section 35.130(f) has met with the criticism that it is unconstitutional or invalid.

49. 42 U.S.C. $\$ 12131(2)$

50. Id. § $12102(2)(\mathrm{A})$.

51. Id. § 12101(a)(2). 
The ADA was passed in 1990 - "an earthshaking event for disabled people." ${ }^{, 52}$ The prohibitions against discrimination, as described above, were in response to the continuous exclusion of people with disabilities from everyday activities like using public buildings, dining out, going to the movies, and even working. ${ }^{53}$ Disability rights activists had shown their outrage about years of unnecessary institutionalization, ${ }^{54}$ and celebrated when the Court announced its decision in Olmstead.

\section{Olmstead v. L.C. ex rel. Zimring}

Two women diagnosed with mental retardation and mental illness had voluntarily admitted themselves into a Georgia hospital for treatment. ${ }^{55}$ One woman remained there three years after stabilizing. ${ }^{56}$ The other woman remained there two years after stabilizing. ${ }^{57}$ The first woman filed suit two years into her stay invoking 42 U.S.C. $§ 1983$ and the ADA, 42 U.S.C. $\S \S 12131-34$; the second woman intervened with identical claims. ${ }^{58}$ In response to the original complaint, Georgia raised a cost-based defense, arguing that "it was already using all available funds to provide services to other persons with disabilities," and that "requiring immediate transfers [to less restrictive environments] in cases of this order would 'fundamentally alter' the State's activity.",59 Ultimately, these women began receiving community-based treatment, but their case still received review by the Supreme Court. ${ }^{60}$

The Supreme Court concluded, solely on ADA grounds, that the institutionalization these women faced was prohibited discrimination: "Specifically, we confront the question whether the proscription of discrimination may require placement of persons with mental disabilities in community settings rather than in institutions. The answer, we hold, is a qualified yes." 61 The Court qualified its decision by stating that placement in a community setting should be made if it "can be reasonably accommodated, taking into account the resources available to

52. SHAPIRO, supra note 27 , at 140 .

53. Id. at $105-06$.

54. See id. at 139-40, 158-65 (discussing stories of institutionalization and the rise of institutionalization).

55. Olmstead v. L.C. ex rel. Zimring, 527 U.S. 581, 593 (1999).

56. Id.

57. Id.

58. Id. at 593-94.

59. Id. at 594 .

60. Id. at 594 n.6.

61. Id. at 587 . 
the State and the needs of others with mental disabilities." ${ }^{22}$ The Court stated that "the State's responsibility... is not boundless." 33 A community placement is preferred to institutional care, but states might not be required to provide community placement for everyone who seeks it. The Court opined, in dicta:

If, for example, the State were to demonstrate that it had a comprehensive, effectively working plan for placing qualified persons with mental disabilities in less restrictive settings, and a waiting list that moved at a reasonable pace not controlled by the State's endeavors to keep its institutions fully populated, the reasonable-modifications standard would be met. ${ }^{64}$

This "comprehensive, effectively working plan" has since been referred to as an Olmstead plan. ${ }^{65}$ Although Georgia's Medicaid waiver program was not at issue, this language has been used by other courts in determining whether states are discriminating against individuals with disabilities who continue to reside in institutions despite the existence of waiver programs designed to increase community placement.

If community-based services are cost-effective ${ }^{66}$ and institutional care is discriminatory, ${ }^{67}$ why is there still a fight - evidenced by yet another initiative to end unnecessary institutionalization ${ }^{68}$ - to keep people with disabilities from moving out of restrictive environments? While Olmstead represents a victory for people with disabilities, ${ }^{69}$ it has not worked with Medicaid as advocates hoped. ${ }^{70}$ Perhaps states are still concerned that "the savings they currently enjoy from these [homebased] programs would evaporate if such help is made widely available," and that people with disabilities will come "out of the woodwork."

62. Id.

63. $I d$. at 603

64. Id. at $605-06$.

65. E.g., Sanchez v. Johnson, 416 F.3d 1051, 1064 (9th Cir. 2005).

66. See supra Part II.A.2 (discussing waiver program cost-effectiveness).

67. See supra Part II.B.1 (discussing Supreme Court's finding that institutionalization is prohibited discrimination under the ADA).

68. See supra note 1 and accompanying text.

69. The Olmstead decision was viewed as "encouraging community-based placement, when appropriate, over institutionalization." Perkins \& Boyle, supra note 37, at 141.

70. See id. at 142-43 ("[W]hile states may be able to cite budgetary constraints to limit their accommodations to achieve integration under the ADA, budgetary constraints alone should not excuse a state from complying with the Medicaid Act.”). See also Sara Rosenbaum et al., Olmstead v. L.C.: Implications for Medicaid and Other Publicly Funded Health Services, 12 HEALTH MATRIX 93, 93 (2002) ("But Olmstead's true importance from a health policy perspective lies in its long-term potential to secure realignment of public spending on health services for persons with disabilities.").

71. ShAPIRO, supra note 27, at 252-53 (please note this book was authored pre-Olmstead). See 
Additionally, some states cite a persistent lack of infrastructure in place to provide in-home care. ${ }^{72}$ Shortly after Olmstead was decided, a number of suits were brought seeking guidance on waiver program requirements. $^{73}$ Despite initial efforts, ${ }^{74}$ the Circuit Courts of Appeals have provided little encouragement in using the ADA to effect deinstitutionalization.

\section{A Collective Right to Freedom from Institutionalization}

The Olmstead Court encouraged states to have "a comprehensive, effectively working plan for placing qualified persons with mental disabilities in less restrictive settings, and a waiting list that moved at a reasonable pace." 75 At the time Olmstead was decided, states, encouraged by the federal government, ${ }^{76}$ were showing increased interest in HCBS waivers. ${ }^{77}$ Waiver programs appeared to be the way to provide the integration mandated by the ADA. Recall, though, that waiver programs work because of their ability to operate outside the "strict mandates of Medicaid."78 Arc of Washington State, Inc. v. Braddock ${ }^{79}$ illustrates this tension between waiver programs, Medicaid requirements, and the Olmstead decision.

In Arc of Washington State, the Arc, a disability-rights group, filed suit against the State of Washington for violations of the ADA, claiming that "Washington's HCBS program [was] too small to accommodate the state's population of eligible participants." ${ }^{\text {" The Arc demanded that }}$

also Perkins \& Boyle, supra note 37, at 119 (discussing that the states' shift to funding services in home and community settings has been delicate because of concerns that "people who are being cared for in institutions or by family members will 'come out of the woodwork' and place heavy demands on limited Medicaid budgets").

72. Knox, supra note 2.

73. See Perkins \& Boyle, supra note 37, at 127-30 (discussing cases arising after Olmstead involving Medicaid waiver program requirements).

74. See id. (discussing federal district court outcomes in suits seeking enforcement of freedom of choice and reasonable promptness provisions of Medicaid for beneficiaries seeking services through HCBS waivers).

75. Olmstead v. L.C. ex rel. Zimring, 527 U.S. 581, 605-06 (1999).

76. See id. at 601 ("Indeed, the United States points out that the Department of Health and Human Services (HHS) 'has a policy of encouraging States to take advantage of the waiver program, and often approves more waiver slots than a State ultimately uses."').

77. 2003 GAO HCBS Oversight Report, supra note 26, at 11 ("By 1992, 48 states operated a total of 155 HCBS waivers. As of June 2002, 49 states and the District of Columbia operated a total of 263 HCBS waivers ....”).

78. Bryson v. Shumway, 308 F.3d 79, 82 (1st Cir. 2002).

79. 427 F.3d 615 (9th Cir. 2005).

80. Id. at 619 . 
Washington "request federal authorization for an increase in the size of its HCBS waiver program." 81

The Ninth Circuit harkened back to the Olmstead escape clause: " "[t]he State's responsibility, once it provides community-based treatment to qualified persons with disabilities is not boundless." 82 The Ninth Circuit reasoned that satisfying the Arc's demands depended on whether changing the size of the HCBS waiver program was a "'reasonable modification' (which is required [by the ADA]) or a 'fundamental alteration' (which is not [required by the ADA]).", Because the court found Washington to have a "comprehensive, effectively working plan" and its "commitment to deinstitutionalization [was] ... 'genuine, comprehensive and reasonable," the court held that requiring an increase in waiver slots would "constitute[] a fundamental alteration, and is not required by the ADA." ${ }^{\prime 4}$ Simply put, the court would not require an increase in the waiver program's size because the state had established a working Olmstead plan.

Arc of Washington State, though not frequently cited, represented an affirmation of the Ninth Circuit's decision in Sanchez ex rel. Hoebel v. Johnson, ${ }^{85}$ and its reasoning was used in Bryson v. Stephen ${ }^{86}$ to prevent another requested expansion of a waiver program to qualified individuals with disabilities seeking community-based services. ${ }^{87}$

While the institutionalization of people with disabilities is a recognized form of discrimination, one person does not have the same individual protection against institutionalization as they would have against other forms of discrimination, such as employment or housing discrimination. Theoretically, the ADA could be used to enforce access to home and community-based services. But in practice it is systemic

\footnotetext{
81. Id.

82. Id. (citing Olmstead, 527 U.S. at 603).

83. Id.

84. Id. at 621-22 (internal citations omitted). Also important to this decision were the following factors:

Washington's HCBS program (1) is sizeable, with a cap that has increased substantially over the past two decades; (2) is full; (3) is available to all Medicaid-eligible disabled persons as slots become available, based only on their mental-health needs and position on the waiting list; (4) has already significantly reduced the size of the state's institutionalized population; and (5) has experienced budget growth in time with, or exceeding, other state agencies.

85. 416 F.3d 1051, 1067-68 (9th Cir. 2005). This case will be discussed in further detail in Part III.B.2, as it relates to $\S 1983$ Medicaid jurisprudence.

86. No. 99-CV-558-SM, 2006 WL 2805238, at*3-6 (D.N.H. Sept. 29, 2006).

87. Id. at $* 5$.
}

Id. 
access - not individual access - which is protected. Consider Jane's dilemma: what can Jane do to move out of the institution and into a community setting within the ADA-waiver program framework? So long as the state Jane lives in has an acceptable Olmstead plan, Jane only has a right to have her name placed on a waiting list and wait until a slot on a waiver program becomes available. What would happen if someone were told that he or she had to wait on a list until a slot became available for her to vote? To go to elementary school? To use the bus? The hurdles imposed by the Olmstead-waiver combination are too high for most individuals. However, other legal frameworks exist through which people with disabilities have sought enforcement of their civil rights.

\section{AN OVERVIEW OF $§ 1983$ AND $§ 1983$ ACTIONS BROUGHT TO ENFORCE MEDICAID PROVISIONS}

Section 1983 imposes liability on individuals acting under the color of law for depriving others of rights protected by the U.S. Constitution and federal law. ${ }^{88}$ To determine whether a federal law contains a federal right, the Supreme Court set forth a test in Blessing v. Freestone ${ }^{89}$ which has since been clarified by Gonzaga University v. Doe. ${ }^{90}$

\section{A. The Blessing Test}

In order to successfully enforce a federal right using $\S 1983$, the plaintiff must demonstrate the following elements. Congress must have intended the statutory provision conferring the right to benefit the plaintiff. 91 The statutory right cannot be so "vague and amorphous' that its enforcement would strain judicial competence." 92 Finally, "the statute must unambiguously impose a binding obligation on the States." "93

The Supreme Court used Gonzaga to clarify the first prong of this test by requiring that nothing less than "an unambiguously conferred right" supports "a cause of action brought under $\S 1983$. ."94 Once the Blessing test is satisfied, "there is a presumption that [the federal statute]

\footnotetext{
88. 42 U.S.C. $\$ 1983$ (2000).

89. 520 U.S. 329 (1997).

90. See 536 U.S. 273, 282-83 (2002) (outlining the Blessing test and clarifying the first prong).

91. Blessing, 520 U.S. at 340.

92. Id.

93. Id.

94. Gonzaga, 536 U.S. at 283.
} 
is subject to private enforcement under section 1983."95 This presumption can be rebutted if "Congress expressly or impliedly foreclosed enforcement under section 1983; an implied foreclosure occurs if Congress created 'a comprehensive enforcement scheme that is incompatible with individual enforcement." 96 The ADA, unlike Medicaid, is an example of a statute with its own comprehensive enforcement scheme. ${ }^{97}$

\section{B. Applications to Medicaid Provisions}

Wilder v. Virginia Hospital Association ${ }^{98}$ first recognized a Medicaid provision as enforceable by $\S 1983 .{ }^{99}$ Although the provision discussed in Wilder is no longer part of Medicaid, Wilder was used in deciding both Blessing and Gonzaga, and still presents pertinent reasoning in $\S$ 1983 Medicaid litigation. Specifically, the Supreme Court held in Wilder that the particular provision "impose[d] a binding obligation on States participating in the Medicaid program to adopt reasonable and adequate rates and that this obligation is enforceable under $\S 1983$ by health care providers." 100 The Court looked to the "mandatory rather than precatory terms" of the statute. ${ }^{101}$ The Court also found that "[t]he Medicaid Act contains no... provision for private judicial or administrative enforcement." 102

Although the Supreme Court has examined $\S 1983$ since Wilder, it has not examined litigation using $\S 1983$ to enforce other Medicaid provisions or the impact the waiver programs might have on whether $\S$ 1983 may still be used to enforce Medicaid provisions. The Circuit Courts of Appeals have addressed multiple § 1983 actions seeking enforcement of various Medicaid provisions, and at times, in light of waiver programs. Comparing the enforceable provisions with those

95. Watson v. Weeks, 436 F.3d 1152, 1158 (9th Cir. 2006).

96. Id. at $1158-59$ (citing Blessing).

97. See 42 U.S.C. $\S 12133$ (2000) (containing the enforcement provisions for violations of the public entity prohibition against discrimination).

98. 496 U.S. 498 (1990), superseded by statute, Balanced Budget Act of 1997, Pub. L. No. 105-33, 111 Stat. 251, as recognized in Roob v. Fisher, 856 N.E.2d 723 (Ind. Ct. App. 2006).

99. Id. at 501-02. Although Wilder has been superseded by statute, similar analysis was used in Blessing and Gonzaga. See Frederick H. Cohen, An Unfulfilled Promise of the Medicaid Act: Enforcing Medicaid Recipients' Right to Health Care, 17 LOY. CONSUMER L. REV. 375, 391 (2005) ("The Supreme Court expressly upheld the enforceability of rights under the Medicaid Act through [s]ection 1983 in Wilder v. Virginia Hospital Association.").

100. Wilder, 496 U.S. at 512

101. Id.

102. Id. at 521 . 
waived in order to enact the HCBS and Demonstration Project waivers shows the extent of waiver impact on individual rights.

1. Doe ex rel. Doe v. Chiles to Sabree v. Richman: Section 1983

Applied Outside of the Waiver Program Context

As required by Gonzaga, courts-determining whether a statute grants "an unambiguously conferred right" that $\S 1983$ may be appropriately used to enforce - must look carefully at the actual language of the statute. ${ }^{103}$ The following cases involve analysis of the Reasonable Promptness, ${ }^{104}$ Quality of Care, ${ }^{105}$ and Equal Access ${ }^{106}$ provisions of Medicaid state plan requirements. Because these cases do not involve waiver programs, each of these provisions must be satisfied by a state's Medicaid plan in order for the state to continue to receive Medicaid funding. ${ }^{107}$ The question is whether an individual can enforce these requirements through $\S 1983$.

In 1998-before Gonzaga - the Eleventh Circuit decided Doe ex rel. Doe v. Chiles, ${ }^{108}$ a case involving people with developmental disabilities seeking enforcement of the Reasonable Promptness Provision under $\S$ 1983 to access services in intermediate care facilities. ${ }^{109}$ The Reasonable Promptness Provision states that a state Medicaid plan must "provide that all individuals wishing to make application for medical assistance under the plan shall have the opportunity to do so, and that such assistance shall be furnished with reasonable promptness to all eligible individuals." After application of the Blessing test, the court held that the Reasonable Promptness Provision constituted "a federal right . . . and that this right is enforceable under section 1983." "111 The statutory language of the Reasonable Promptness Provision "is undoubtedly cast in mandatory rather than precatory terms," as evidenced by the use of "shall" and "must."112 Although the court found the Reasonable Promptness Provision to be enforceable with $\S 1983$ under the Blessing test, the

\footnotetext{
103. See supra Part III.A.

104. See supra notes $16-17$ and accompanying text.

105. See supra notes 18-19 and accompanying text.

106. See supra notes 21-22 and accompanying text.

107. See supra Part II.A.2 (explaining the mechanics of Medicaid waiver programs).

108. 136 F.3d 709 (11th Cir. 1998).

109. Id. at 711 .

110. 42 U.S.C. § $1396 a(a)(8)(2000)$

111. Doe, 136 F.3d at 719 .

112. Id. at 718 .
} 
Eleventh Circuit has not revisited the issue since, and in light of, Gonzaga.

To further place this decision in its historical context, Doe was decided before Olmstead, ${ }^{113}$ but Olmstead also originated in the Eleventh Circuit. ${ }^{114}$ Furthermore, although the ADA had been enacted for two years at the time the suit was filed, no discrimination claims were brought under the ADA. ${ }^{115}$ No Medicaid waiver was at issue, either.

In 2003, the Seventh Circuit decided Bruggeman ex rel. Bruggemen v. Blagojevich, a case involving both Medicaid and ADA violations. ${ }^{116}$ Unfortunately, Bruggeman is not particularly helpful. The decision lacks $\S 1983$ and implied-right analysis, and remands the ADA claim for determination as to whether Illinois had an Olmstead-type plan. ${ }^{117}$ The case is more helpful for developing the definition of medical assistance as "financial assistance rather than ... actual medical services."

In 2004, the Third Circuit decided Sabree ex rel. Sabree $v$. Richman, ${ }^{119}$ a $\S 1983$ claim from Plaintiffs with mental retardation "in need of medical services from an intermediate care facility for persons with mental retardation." 120 The Plaintiffs were Medicaid-qualified but had not yet received Medicaid assistance from Pennsylvania. ${ }^{121}$ The court determined that both the Reasonable Promptness and the Quality of Care Provisions of Medicaid were enforceable under $\S 1983$ using Gonzaga-analysis. ${ }^{122}$ Again the court looked to the statute's use of "shall" and "must" in both provisions and found that these terms were "rights-creating terms" with an "individual focus." 123 The court stated, "it is evident... that the statutory language, despite countervailing structural elements of the statute, unambiguously confers rights which plaintiffs can enforce."124 The Third Circuit found that both the Reasonable Promptness and Quality of Care Provisions met the Gonzaga

\footnotetext{
113. Id. at 709 .

114. Olmstead v. L.C. ex rel. Zimring, 527 U.S. 581, 587 (1999) (affirming the Eleventh Circuit's decision "in substantial part").

115. See Doe, 136 F.3d at 711. For a summary and discussion of Doe ex rel. Doe v. Chiles in greater detail, see Wiggins, supra note 24, at 1496-97.

116. 324 F.3d 906 (7th Cir. 2003).

117. Id. at $908,910,913$.

118. Id. at 910. See also supra notes $23-24$ and accompanying text (discussing the definition of medical assistance).

119. 367 F.3d 180 (3d Cir. 2004).

120. Id. at 181 .

121. Id.

122. Id. at $182,193-94$

123. Id. at 189-90.

124. Id. at 192.
} 
requirements for fulfillment of the Blessing test. ${ }^{125}$ Much like Doe ex rel. Doe v. Chiles, though, the Plaintiffs only sought relief with $\S 1983$ and not under the ADA, and therefore no waiver programs were at issue.

Also in 2004, the First Circuit heard Long Term Care Pharmacy Alliance v. Ferguson. ${ }^{126}$ The case involved pharmaceutical providers seeking enforcement of individual rights under the Equal Access Provision, claiming rates for pharmaceuticals would be insufficient under a proposed scheme. ${ }^{127}$ The Equal Access Provision requires state Medicaid plans to provide "such methods and procedures relating to the utilization of, and the payment for, care and services available under the plan... to assure that payments are ... sufficient to enlist enough providers so that care and services are available under the plan" to the extent the services are available to the general population of that area. ${ }^{128}$ Specifically reviewing the provision under Gonzaga, the court found "no "rights creating language" and "no discrete class of beneficiaries." 129 The court held that the statute was not particular enough to grant individual enforcement rights. ${ }^{130}$ Once again no waiver program was in issue or discussed throughout.

After a review of the non-waiver $\S 1983$ Medicaid cases, the Circuit Courts of Appeals appear to be somewhat in agreement: the Reasonable Promptness and Quality of Care Provisions are enforceable under $\S$ 1983, the Equal Access Provision is not enforceable under $\S 1983$, and nothing clear has been stated on the interaction between rights under Medicaid and rights under the ADA.

2. Bryson v. Shumway, Watson v. Weeks, and Mandy R. ex rel. Mr. \& Mrs. R. v. Owens: Section 1983 in a Waiver Program Context

Each of the following cases involves a plaintiff seeking enforcement of a Medicaid state plan requirement in light of an existing waiver program through $\S 1983$. Pay particular attention to the interpretation of the Reasonable Promptness Provision in light of the existing waiver programs.

In the 2002 case Bryson v. Shumway, the First Circuit found the Reasonable Promptness Provision of Medicaid enforceable using § 1983,

125. Id. at 189

126. 362 F.3d 50 (1st Cir. 2004).

127. Id. at 56,59 .

128. 42 U.S.C. $\S 1396 a(a)(30)(A)(2000)$.

129. Long Term Care Pharm. Alliance, 362 F.3d at 57.

130. Id. at $58-59$. 
but this time a waiver program was involved. ${ }^{131}$ In 1993, New Hampshire had sought and received an HCBS model waiver to provide home and community-based services to individuals with acquired brain disorders. ${ }^{132}$ The model waiver "differs from regular waivers primarily in that model waivers . . may not serve more than 200 individuals at any one time." ${ }^{\prime 133}$ From 1993 until the decision date in 2002, New Hampshire had consistently requested additional waiver slots, but was still under the 200 person limit. ${ }^{134}$

The Plaintiffs in Bryson were waiver-eligible individuals that had been placed on a waiting list. ${ }^{135}$ They claimed that the number of waiver slots should be "as many slots as the number of applicants, up to a limit of 200," and that when a waiver slot became available, the slots were not filled within a reasonable time. ${ }^{136}$ The court reasoned against a requirement of at least 200 slots in the model waiver program, ${ }^{137}$ but more importantly, the court commented on how the Reasonable Promptness Provision applied to the waiver program. Specifically, the court reasoned: "Those patients who are on the waiting list and for whom slots are available are, we think, 'eligible' under the statute such that they are entitled to reasonable promptness." 138 This means that in order to receive reasonably prompt medical assistance under New Hampshire's HCBS waiver, an individual must already be on a waiting list for waiver services and a waiver slot must be available. This decision came after Olmstead, but the Court did not address discrimination claimed under the ADA. ${ }^{139}$

In 2005, the Ninth Circuit handled a combination case in which Plaintiffs, a group of individuals with developmental disabilities, claimed violations of the Equal Access Provision of Medicaid, as well as discrimination under the ADA. ${ }^{140}$ More specifically, the Plaintiffs alleged that "because California pays wages to community-based service providers participating in the HCBS waiver program at a lower rate than

\footnotetext{
131. 308 F.3d 79, 81, 89 (1st Cir. 2002).

132. Id. at $82-83$.

133. Id. at 83 (citing 42 C.F.R. $\S 441.305$ (b)(1) (2002)).

134. Id.

135. Id. at 81,83

136. Id. at 81

137. Id. at 86 ("This statute, $\S 1396 \mathrm{n}(\mathrm{c})(10)$, is most plausibly read as limiting only the ability of the Secretary to impose such restrictions, and not the ability of the states to propose or the Secretary to approve waiver plans serving fewer than 200 individuals.").

138. Id. at 88 (internal citation omitted).

139. Id. at $83-84$.

140. Sanchez ex rel. Hoebel v. Johnson, 416 F.3d 1051, 1053, 1055 (9th Cir. 2005).
} 
it pays employees in state institutions, the State is in violation of the [Equal Access Provision] of the Medicaid Act...."141 The Plaintiffs also alleged that "the lower pay in community-based programs... resulted in some developmentally disabled persons remaining unnecessarily institutionalized, which... constitutes discrimination against them in violation of the ADA ...,"142 The Plaintiffs were attempting to engage the court in analyzing a Medicaid waiver program in conjunction with the ADA through the Equal Access Provision.

In examining the $\S 1983$ claim, the court used recently-decided Gonzaga along with the reasoning in Long Term Care Pharmacy v. Ferguson to find that the Equal Access Provision did not include rightscreating language. ${ }^{143}$ The court recognized pre-Gonzaga decisions which did find a $\S 1983$-enforceable right in this provision, but held that "there is nothing in the text of $\S 30(\mathrm{~A})$ that unmistakably focuses on recipients or providers as individuals. Moreover, the flexible administrative standards embodied in the statute do not reflect a Congressional intent to provide a private remedy for their violation."144 Given the overall agreement by the circuits that the Equal Access Provision is not $\S 1983$ enforceable regardless of the waiver, this result is not surprising. ${ }^{145}$

As for the discrimination claims, the court found that the existence of an acceptable "Olmstead Plan" precluded mandating increased home and community-based services, a "'fundamental alteration' of a comprehensive, working plan for deinstitutionalization." "146 This same line of reasoning was used by the Ninth Circuit in dismissing institutionalization-discrimination claims in Washington. ${ }^{147}$

In 2006, the Ninth Circuit handled Watson v. Weeks, another waiver case brought using $\S 1983 .{ }^{148}$ Oregon had scaled back its home and community-based services under Medicaid in response to budgetary concerns. $^{149}$ When a group of individuals lost their HCBS services as part of these cutbacks, they-along with their legal representativesworked with the Oregon Advocacy Center to fight back. ${ }^{150}$ Though their

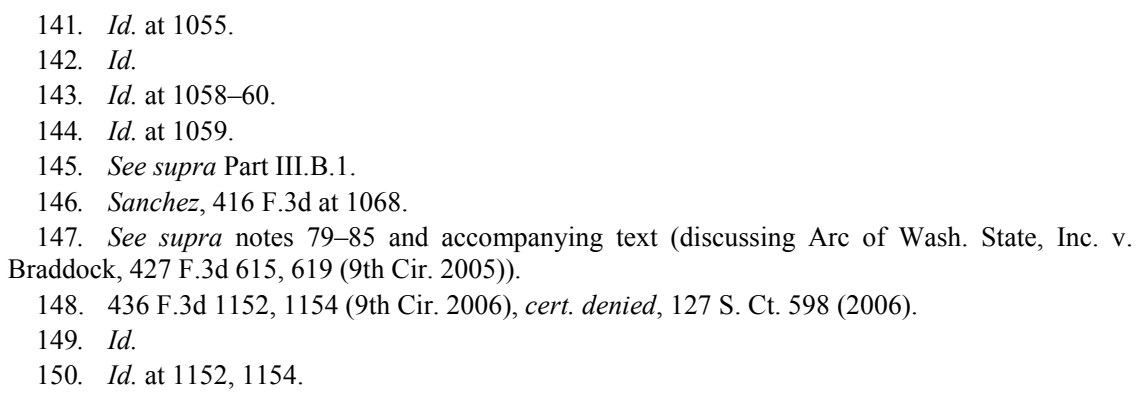


original claims were dismissed by the District Court, the Ninth Circuit found that the Plaintiffs could use $\S 1983$ to enforce their rights under the Medicaid Quality of Care Provisions, ${ }^{151}$ but found that another provision requiring states to use reasonable standards in eligibility determinations ${ }^{152}$ did not provide an "unambiguously conferred right" and was "too vague and amorphous for judicial enforcement," thus failing the Blessing test. ${ }^{153}$

Also in 2006, the Tenth Circuit addressed accessing Medicaid waiver programs under $\S 1983$ in Mandy R. ex rel. Mr. \& Mrs. R. v. Owens. ${ }^{154}$ Plaintiffs, people with developmental disabilities on Colorado's HCBS waiver program waiting list, sought to enforce access to the HCBS services through the Reasonable Promptness Provision, the Quality of Care Provision, and the Equal Access Provision. ${ }^{155}$

The court, for purposes of this case, assumed enforceability of the Reasonable Promptness and Quality of Care Provisions under $\S 1983$, but rejected claims under both because "medical assistance" is defined as "payment for, but not provision of, services." "156 Using this definition in connection with these two provisions, the court found:

[T] he Medicaid Act requires any state participating in Medicaid to pay promptly and evenhandedly for medical services when the state is presented with the bill. If that is all the statute requires, then the plaintiffs have no claim: they are on a waiting list for services, not a waiting list for payment for services. ${ }^{157}$

The Tenth Circuit went on to hold that no enforceable right existed under the Equal Access Provision of Medicaid. ${ }^{158}$

The $\S 1983$ Medicaid waiver cases do not differ dramatically from the non-waiver cases. Yet, the interpretation of the Reasonable Promptness Provision in this line of cases creates a particular barrier. An individual eligible for waiver program services has the right to reasonably prompt payment of those services and, possibly, reasonably prompt access to a slot once a slot becomes available. Regardless of

151. Id. at 1161 (discussing $\S 1396 \mathrm{a}(\mathrm{a})(10)$ generally as opposed to $\S 1396 \mathrm{a}(\mathrm{a})(10)(\mathrm{B})$ specifically).

152. 42 U.S.C. $§ 1396 a(a)(17)(2000)$

153. Watson, 436 F.3d at 1162 .

154. 464 F.3d 1139 (10th Cir. 2006), cert. denied, 127 S. Ct. 1905 (2007).

155. Id. at 1141 . The Tenth Circuit refers to the Quality of Care Provision as the "Comparability Provision," and to the Equal Access Provision as the "Sufficient Payment Provision."

156. Id. at 1143 .

157. Id.

158. Id. at 1148 . 
whether medical assistance includes anything other than payment for services, there is no right to reasonably prompt waiver program services unless a slot is available. An individual cannot seek redress for lack of waiver program availability.

\section{The EPSDT Twist}

There are several important cases in the $\S 1983$ Medicaid line that have not yet been discussed. The following cases involve Medicaid beneficiaries trying to enforce a right of access to Early Periodic Screening and Diagnostic Testing (EPSDT) using $\S 1983 .{ }^{159}$ Westside Mothers v. Olszewski, ${ }^{160}$ Pediatric Specialty Care, Inc. v. Arkansas Department of Human Services, ${ }^{161}$ S.D. ex rel. Dickson v. Hood, ${ }^{162}$ and Oklahoma Chapter of the American Academy of Pediatrics (OKAAP) $v$. Fogarty $^{163}$ represent courts grappling with the provision of EPSDT services to children and youth twenty-one and under. Westside Mothers also illustrates the ongoing nature of Medicaid litigation, the original action having been filed in $1999 .{ }^{164}$

While children can often be served by waiver programs, ${ }^{165}$ the EPSDT language guarantees a broad array of services without requiring waiver access and has been held to contain a right to those services enforceable by $\S 1983 .{ }^{166}$ EPSDT differs significantly from the Medicaid provisions discussed above. Particularly, EPSDT changes the definition of medical assistance to include "other diagnostic, screening, preventive, and rehabilitative services, including any medical or remedial

\footnotetext{
159. A right of access to EPSDT is conferred by 42 U.S.C. $§ 1396 \mathrm{~d}(\mathrm{a})(13)$ (2000).

160. 454 F.3d 532 (6th Cir. 2006).

161. 443 F.3d 1005 (8th Cir. 2006), vacated in part on other grounds, 127 S. Ct. 3000 (2007).

162. 391 F.3d 581 (5th Cir. 2004).

163. 472 F.3d 1208 (10th Cir. 2007), cert. denied, 128 S. Ct. 68 (2007).

164. 454 F.3d at 536. In fact, earlier decisions in the Westside Mothers litigation caused quite a stir among scholars. See, e.g., Erwin Chemerinsky, Ensuring the Supremacy of Federal Law: Why the District Court Was Wrong in Westside Mothers v. Haveman, 12 Health MatriX 139, 139-40 (2002) (stating that the Westside Mothers decision "is fundamentally wrong and dangerous to ensuring the supremacy of federal law"); Michael A. Platt, Comment, Westside Mothers and Medicaid: Will This Mean the End of Private Enforcement of Federal Funding Conditions Using Section 1983?, 51 AM. U. L. REV. 273, 273 (2001) (stating that the Westside Mothers "proposition has sent shock waves throughout the public interest community").

165. Kansas provides waiver services to children with disabilities through the Mental Retardation/Developmental Disability Waiver, the Physical Disability Waiver, the Technology Assistance Waiver, and the Severe Emotional Disturbance Waiver. Kansas Social and Rehabilitation Services, http://www.srskansas.org/services.htm (last visited Oct. 8, 2007) (follow cascading menu for children services).

166. Dickson, 391 F.3d at 604; Westside Mothers, 454 F.3d at 538; Pediatric Specialty, 443 F.3d at 1008 .
} 
services (provided in a facility, a home, or other setting) recommended by a physician ... for the maximum reduction of physical or mental disability and restoration of an individual to the best possible functional level" for children twenty-one and under. ${ }^{167}$ None of these cases address EPSDT in the context of a waiver program and the cases conflict over enforceability of the Equal Access Provisions and over the definition of medical assistance.

Westside Mothers and Pediatric Specialty, though both finding EPSDT an enforceable right, agree on little else. Westside Mothers clearly limits medical assistance to financial assistance and denies $\S 1983$ enforceability of the Equal Access Provision. ${ }^{168}$ Pediatric Specialty, on the other hand, broadly interprets the Equal Access Provision to be individually enforceable under $\S 1983$, and rather than limit "medical assistance," the Court found the Plaintiffs to have "clearly established rights to provide and receive medically necessary health care."169 $O K A A P$ does not explicitly find EPSDT as an enforceable right but rather continues the Tenth Circuit's conclusions in Mandy $R$. that medical assistance is only financial payment for medical services and EPSDT is just a form of medical assistance. ${ }^{170}$

In district courts around the country, EPSDT continues to be enforced even for innovative services like "wraparound services"- the practice of serving a child in each aspect of his or her life without compartmentalizing need, thus "wrapping" the services "around" the child. In Katie A. v. Bonta, the District Court for the Central District of California acknowledged a $\S 1983$ right to enforcement of EPSDT services, ${ }^{171}$ and concluded that the EPSDT statute provided for medically necessary wraparound services and therapeutic foster care. ${ }^{172}$ In the District of Massachusetts, children with severe emotional disturbance were able to access EPSDT services via $\S 1983$ for comprehensive assessment services. ${ }^{173}$ While the interaction between waiver programs and EPSDT has not been clearly addressed by the courts, an enforceable right to EPSDT has not met the same resistance, and cannot be waived in the same way, as the other state plan requirements. Furthermore, EPSDT language is more mandatory than precatory, and has withstood

167. 42 U.S.C. $§ 1396 d(a)(13)(2000)$.

168. 454 F.3d at $540,543$.

169. 443 F.3d at 1017.

170. OKAAP, 472 F.3d 1208, 1215 (10th Cir. 2007).

171. 433 F. Supp. 2d 1065, 1071 (C.D. Cal. 2006), rev'd and remanded on other grounds, 481 F.3d 1150 (9th Cir. 2007).

172. Id. at 1073 .

173. Rosie D. v. Romney, 410 F. Supp. 2d 18, 52 (D. Mass. 2006). 
challenges under Gonzaga. Even if EPSDT is only the financial provision of that set of medical services, all eligible individuals should be able to access these services regardless of the existence of a waiver program, alleviating concerns about EPSDT under Medicaid's more managed-care-like atmosphere. ${ }^{174}$

\section{Using $§ 1983$ to Enforce Medicaid Provisions in a Waiver System}

The most important difference inherent in $\S 1983$ litigation involving Medicaid waiver cases lies in the interpretation of the Reasonable Promptness Provision. Even setting aside the extreme nature of Mandy $R .,{ }^{175}$ the Reasonable Promptness Provision has primarily been interpreted to mean that no more than a reasonable time should pass between the opening of a waiver slot to the filling of that slot by a qualified beneficiary. This interpretation-combined with the fact that no appellate court has found discrimination in a limited waiver program-shows that while an individual receiving typical fee-forservice Medicaid services has a right to reasonably prompt medical assistance, an individual qualified to receive waiver services only has a right to reasonably prompt medical assistance once a slot on the waiver becomes available. There is no requirement to make waiver services available for an individual if, systemically, the state in question has an Olmstead-plan.

Each of the waiver programs discussed in a $\S 1983$ context were HCBS waivers, which still require compliance with a majority of the state plan requirements. ${ }^{176}$ Perhaps no $\S 1983$ Demonstration Project waiver cases have been published because waiving all state plan requirements waives any $\S 1983$-enforceable right.

One possible bright spot in this analysis lies with the EPSDT guarantee for children. Unlike other provisions of Medicaid, EPSDT cannot be waived by HCBS waivers. ${ }^{177}$ Unfortunately, EPSDT might be able to be waived by Demonstration Project waiver programs or the new DRA waiver programs. ${ }^{178}$ However, with HCBS waivers still composing

174. See generally John A. Flippen, Note, The Early and Periodic Screening, Diagnostic, and Treatment Program and Managed Medicaid Mental Health Care: The Need to Reevalute the EPSDT in the Managed Care Era, 50 VAND. L. REV. 683 (1997).

175. Mandy R. ex rel. Mr. \& Mrs. R. v. Owens, 464 F.3d 1139, 1143 (10th Cir. 2006) ("[T]hey are on a waiting list for services, not a waiting list for payment for services.").

176. See supra notes 30-37 and accompanying text (describing HCBS waivers).

177. 42 U.S.C. $\S 1396 n$ (c) (2000).

178. See infra Part IV.B.1 (describing DRA waivers). 
the majority of waiver programs, seeking enforcement of EPSDT access under $\S 1983$ should not only be feasible but successful.

When comparing possible HCBS waiver services ("case management services, homemaker/home health aid services and personal care services... habilitation services, respite care" ${ }^{\text {"179) }}$ ) with EPSDT benefits ("any medical or remedial services... recommended by a physician or other licensed practitioner of the healing arts within the scope of their practice under State law, for the maximum reduction of physical or mental disability and restoration of an individual to the best possible function level"180), there is hope that, at least eligible children with disabilities can be free from the discrimination prohibited by the ADA in the administration of Medicaid.

\section{New Concerns Require NeW StRAtegies to Preserve the RIGHTS OF PEOPLE WITH DISABILITIES}

Reconsider Jane's dilemma in light of $\S 1983$ Medicaid cases. As discussed under the Olmstead-waiver program construction, Jane cannot use the ADA to enforce her right to services in a more integrated setting so long as the state she lives in has made a commitment to deinstitutionalization, as evidenced by an Olmstead-type plan. ${ }^{181}$ If Jane's state has a waiver program to address her particularized need, she can only use $\S 1983$ to enforce reasonably prompt access to services once a slot in that waiver program becomes available.

Considering the wide array of new and existing waiver programs, it is extremely unlikely that Jane lives in a state without a waiver program for which she is eligible. ${ }^{182}$ But perhaps in that unlikely situation, Jane would be able to prove discrimination under the ADA. Even so, would Jane be able to transfer her institutional Medicaid to a community placement without an existing waiver program? Olmstead did not answer this question-Georgia did have a waiver program in place for which the Plaintiffs were eligible. ${ }^{183}$ The Court did state, though, that states must provide community placement when community placement is not only appropriate and unopposed by the affected person, but "can be reasonably accommodated, taking into account the resources available to

\footnotetext{
179. 42 U.S.C. $\$ 1396 n(c)(4)(B)$.

180. Id. $\S 1396 \mathrm{~d}(\mathrm{a})(13)$.

181. See supra Part II.B.3.

182. See CMS Waiver Program List, supra note 36 (identifying at least one waiver program operating in each of the fifty states and the District of Columbia).

183. Olmstead v. L.C. ex rel. Zimring, 527 U.S. 581, 602-03 (1999).
} 
the State and the needs of others with mental disabilities." 184 The reason waiver programs were created in the first place was to account for Medicaid's inability to efficiently serve individuals requiring an array of services.

It seems that not much has been accomplished in securing an enforceable right to reasonably prompt Medicaid services - a service of public accommodation - in the most integrated setting as required by the ADA. Commentators argue whether any Medicaid provision should be enforceable with $\S 1983$. $^{185}$ The definition of "medical assistance" limits what a Medicaid entitlement actually is: payment for services, not provision of services. ${ }^{186}$ Medicaid reform is pushing toward more waivers and managed care. ${ }^{187}$ This outlook, combined with the bleak analysis of existing individual rights to de-institutionalization presented above, necessitates innovation.

\section{A. The Lankford Answer}

\section{Lankford v. Sherman}

In response to Missouri's state budget crisis, its legislature revised a statute which provided durable medical equipment (DME) as a standalone benefit to all Medicaid recipients. ${ }^{188}$ Under the new statute, only Medicaid recipients "who are blind, pregnant, or needy children, or ... those who receive home health care services under the state plan" could receive durable medical equipment as a Medicaid service. ${ }^{189}$ Plaintiffs, Medicaid beneficiaries who had received DME previously, ${ }^{190}$ asserted "violations of federal comparability and reasonable-standards requirements that the State treat Medicaid recipients equally and with reasonable, non-discriminatory standards" $"$ and claimed the new "state

184. Id. at 607 .

185. See Mark Andrew Ison, Note, Two Wrongs Don't Make a Right: Medicaid, Section 1983 and the Cost of an Enforceable Right to Health Care, 56 VAND. L. REV. 1479, 1481-82 (2003) (arguing against enforceability of Medicaid using § 1983); Joshua Tenzer, Note, Reaching the Final Frontiers in Medicaid Managed Care, 62 N.Y.U. ANN. SuRV. AM. L. 329, 331 (2006) ("Medicaid should apply the managed care model consistently across Medicaid.").

186. Timothy Stoltzfus Jost, The Tenuous Nature of the Medicaid Entitlement: Federal Rights Remain Under Threat and Must Be Strengthened, 22 HEALTH AFF. No. 1, 145, 145 (2003).

187. John V. Jacobi, Dangerous Times for Medicaid, 33 J.L. MED. \& ETHICs 834, 836-37 (2005); Perkins \& Boyle, supra note 37, at 119.

188. Lankford v. Sherman, 451 F.3d 496, 501 (8th Cir. 2006).

189. Id

190. Id.

191. Specifically, the Plaintiffs asserted that both 42 U.S.C. $§ 1396 a(a)(10)(B)$, the Quality of 
regulation conflict[ed] with these federal requirements, and [was] preempted by the Supremacy Clause." 192 While this case does not discuss any of the Medicaid waiver programs, it does address the Quality of Service and the Reasonable Standards Provisions of Medicaid: the Quality of Service Provision was not violated ${ }^{193}$ and $\S 1983$ cannot be used to enforce the Reasonable Standards Provision. ${ }^{194}$

However, the case did not end there. The Eighth Circuit evaluated the new DME regulation under the preemption doctrine because, according to Plaintiffs, the regulation "directly conflict[ed] with Medicaid's reasonable-standards requirements."195 Under the preemption doctrine, "state laws that 'interfere with, or are contrary to the laws of [C]ongress, made in pursuance of the constitution' are preempted." 196 Because the Medicaid Act does not "expressly preempt[] or entirely displace[] state regulation in a specific field ... "state law is preempted to the extent that it actually conflicts with federal law.",197 Because Missouri receives federal Medicaid dollars, it is required to "comply with Medicaid's reasonable-standards requirement, and its implementing regulations." 198 The restricted nature of Missouri's DME regulation, according to the court, "appear[ed] unreasonable under directives from both CMS and this court." ${ }^{199}$ Accordingly, the court found "a likelihood of success on the merits of the preemption claim" allowing Plaintiffs to proceed in their case for a preliminary injunction against the state. ${ }^{200}$

\section{Supremacy Clause Claim Feasibility}

Although the Lankford $v$. Sherman development has sparked excitement among disability rights activists as a new possible avenue for relief, the case does not actually hold that a federal Medicaid statute preempts the state's relevant Medicaid regulation. ${ }^{201}$ Although success

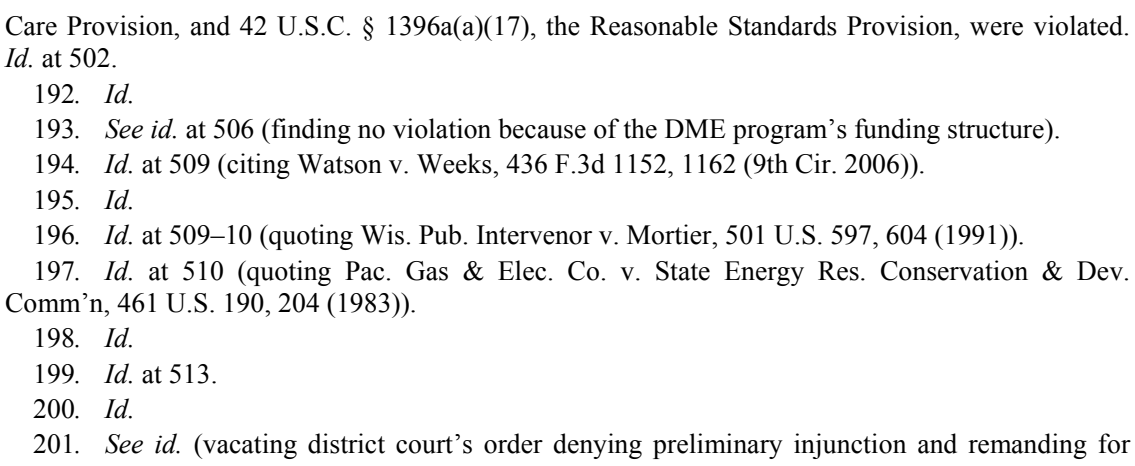


on the merits was considered likely, it had not yet occurred. Unfortunately, other plaintiffs have seen little success when attempting to enforce Medicaid rights asserting violations of the Supremacy Clause.

Particularly, in Equal Access for El Paso, Inc. v. Hawkins, ${ }^{202}$ the court found the Plaintiffs' Supremacy Clause claim "functionally equivalent to Plaintiffs" claim under $\S 1983$," and held that "Plaintiffs do not state a cognizable claim under the Supremacy Clause that is distinct from their $\S 1983$ claim pursuant to the Equal Access Provision."203 The Plaintiffs did have "standing to allege that [the state Medicaid program's] implementation of Medicaid violate[d] the Supremacy Clause in that it [was] inconsistent with certain provisions of the Medicaid Act." ${ }^{204}$ But the Plaintiffs' two-fold Supremacy Clause claim failed to identify a portion of the state statute which conflicted with federal law. ${ }^{205}$

As $§ 1983$-enforceable rights to Medicaid erode under the increased use of waiver programs, and the ADA's de-institutionalization mandate is seen as systemic rather than as an individual right, could the Supremacy Clause breathe new life into the disability rights movement in the legal community? At this time, it is unclear what leeway courts will give plaintiffs in this new realm of pleading. However, neither Lankford nor Equal Access addressed a waiver program problem. Given the substantial control states have over Medicaid programs in general, and the waiver programs specifically, it seems unlikely that a court will find state statutes conflicting with federal Medicaid law amid the enactment of waiver programs - programs designed to operate outside of federal regulation. ${ }^{206}$

\section{B. Further Devolution}

In 1997, the Balanced Budget Act "appreciably lessened federal control over state managed-care programs." ${ }^{207}$ As states increase their governing capacity - "the ability to formulate coherent, creative, plausible policy and carry it out efficiently, effectively, and

further proceedings).

202. 428 F. Supp. 2d 585 (W.D. Tex. 2006), rev'd and remanded on other grounds, No. 0650599, 2007 WL 4295380 (5th Cir. Dec. 10, 2007).

203. Id. at 624 (citation omitted).

204. Id. at 608 .

205. Id. at $607-08$.

206. For an overview of the ADA's constitutionality, or potential unconstitutionality, see James Leonard, The Shadows of Unconstitutionality: How the New Federalism May Affect the AntiDiscrimination Mandate of the Americans with Disabilities Act, 52 ALA. L. REV. 91 (2000).

207. James W. Fossett, Managed Care and Devolution, in MediCAID AND Devolution, 106, 106 (Frank J. Thompson \& John J. Dilulio, Jr. eds., 1998). 
accountably"-more administrative control rests with the states, as opposed to the federal government, in Medicaid's administration. ${ }^{208}$ This is clearly evidenced by further ceding of Medicaid control to the states through the DRA.

However, federal control, especially over "eligibility and benefits," can protect Medicaid beneficiaries from "states' reacting to bad economic times by cutting Medicaid programs." 209 With over one-third of all Medicaid dollars being spent on long-term care for people with disabilities and the elderly, ${ }^{210}$ disability rights advocates should carefully follow how Medicaid programs are being restructured at both the state and federal level.

\section{The Deficit Reduction Act}

As previously mentioned, the Deficit Reduction Act of 2005 made additional changes to Medicaid. Significantly, "[t]he DRA also creates two new waiver authorities" and "allows states to implement some policies that would have required a waiver from the Secretary before the passage of the DRA." 211 The DRA is intended to produce close to five billion dollars in "net savings to the federal government over the next five years" through its wide array of changes to federal Medicaid. ${ }^{212}$

Some of the policy changes states can now make through state plan amendments include basically eliminating the Quality of Care Provision requirement. $^{213}$ This means that now, under traditional Medicaid, states can opt out of providing services which "shall not be less in amount, duration, or scope than the medical assistance made available to any other such individual." 214 While the waiver programs (which were not eliminated by the DRA) operate under the discretion of the Secretary of Health and Human Services, the state plan amendment procedure is less formal and allows the Secretary less discretion in deciding whether to accept the policy change. ${ }^{215}$ Changing policy through state plan amendments will also "result in additional federal spending" because

\footnotetext{
208. Frank J. Thompson, Federalism and the Medicaid Challenge, in MEDICAID AND DEVOLUTION, supra note 207, at 258, 260.

209. Jacobi, supra note 187 , at 840 .

210. 2006 KFF Medicaid State Survey, supra note 7, at 11.

211. RUDOWITZ \& SCHNEIDER, supra note 29, at 2.

212. Id. at 11 .

213. See id. at 12 (discussing flexibility given to states to provide "different 'benchmark' benefit packages to individuals").

214. 42 U.S.C. § $1396 \mathrm{a}(\mathrm{a})(10)(\mathrm{B})(\mathrm{i})(2000)$.

215. RUDOWITZ \& SCHNEIDER, supra note 29 , at 9-10.
} 
unlike the budget-neutral waiver programs, if a state plan amendment "is consistent with the federal Medicaid requirements, the Secretary is obligated to approve it." 216

These policy changes have not been viewed under a judicial lens yet, ${ }^{217}$ but the changes appear to offer even greater flexibility to the states in implementing Medicaid while remaining eligible for federal dollars. Furthermore, the ability of states to sidestep the Quality of Care Provision potentially eliminates the enforceability of that provision under $\S 1983$ by any Medicaid beneficiary-not just waiver program participants.

\section{Money Follows the Person}

On November 1, 2006, the states submitted to the federal government applications to receive part of 1.75 billion dollars in grant money to assist moving individuals in institutions to more integrated environments. ${ }^{218}$ This grant money will be disbursed to state Medicaid programs in the form of Money Follows the Person Real Choice Systems Change grants. ${ }^{219}$ These grants are designed to help states increase home and community-based services by eliminating the barriers between types of funding-typical fee-for-service Medicaid and Medicaid waiver programs. $^{220}$ Ultimately, more Medicaid dollars will go toward home and community-based services. This certainly is an idealistic goalinstitutionalization is discriminatory, and providing additional HCBS services satisfies more people with disabilities and their desire to live in an integrated setting. ${ }^{221}$

But the following question remains unanswered: What happened to the right to services in the most integrated setting? This right is clearly protected by the ADA. An attempt to enforce this right was made in

216. Id. at 10 .

217. Challenges to the constitutionality of the DRA are under way due to a discovery after its passage that "a typographical error had caused each house of Congress to pass a different version of the bill." Kelly S. Davis et al., Medicaid: From the Frying Pan into the Fire, WYo. LAw., Dec. 2006 , at 25-26.

218. Knox, supra note 2.

219. CTRS. For MedicAid and MedicARe, ReAl ChOiCE OVERview, http://www.cms.hhs.gov/ RealChoice/01_Overview.asp (last visited Oct. 8, 2007).

220. Wayne L. Anderson et al., Money Follows the Person Initiatives of Systems CHANGE GRANTEES: FINAL REPORT 21 (2006), available at http://www.cms.hhs.gov/RealChoice/ downloads/MFP.pdf.

221. See Batavia, supra note 25, at 18-19 (noting consumer-directed personal assistance services provide the "significant benefits [of] consumer autonomy, satisfaction, and improved health and function"). 
Olmstead. Yet neither the ADA nor $\S 1983$ have been able to make this right enforceable under Medicaid - the primary funding source for home and community-based services.

Will individuals be able to remain in the community if and when the Medicaid funds are eliminated or eligibility-determinations are greatly altered? These are both real possibilities when operating state Medicaid programs outside federal regulations. Without the cost-containment structure of previous waiver programs, will Money Follows the Person grants lead to the ultimate bankrupting of the Medicaid system? While this type of panicked thinking appears contrary to the aims under which Money Follows the Person was passed, the absence of regulatory oversight, combined with the present entitlement problem for home and community-based services, presents valid fears for individuals relying on these very grants to finally experience freedom.

\section{Eliminating Traditional Medicaid?}

Professor Timothy Stoltzfus Jost has argued for a complete overhaul of the American health care system. ${ }^{222}$ The new system would "wholly replace" Medicaid, and Professor Jost asserts that "few would mourn its passing." ${ }^{223}$ Considering Medicaid's expense, complexity, and lessening entitlement, Professor Jost might be right. However, while sweeping political changes are difficult to make, making them in a way that keeps a safety net under the very people Medicaid is attempting to serve would be next to impossible.

Professor Jost refers to Medicaid as "fifty different programs [dealing] with what is essentially a national problem."224 However, when taking all of the waiver programs into account, alongside the traditional fee-for-service structure, there are closer to five hundred partially federally-funded programs serving one-sixth of the American populous. Considering further that most home and community-based services are provided to only fourteen percent of Medicaid enrollees, over four hundred programs serve two percent of Americans. ${ }^{225}$

222. See Timothy Stoltzfus Jost, Our Broken Health Care System and How to Fix It: An Essay on Health Law and Policy, 41 WAKe Forest L. REV. 537, 540 (2006) (describing the system as a "hodgepodge of laws").

223. Id. at 610 .

224. Id. at 608 .

225. Compare id. (noting the futility of creating multiple programs to handle a national problem) with 2006 KFF Medicaid State Survey, supra note 7, at 11 (discussing the distribution of Medicaid enrollees and expenditures). 
Professor Jost begins his argument by outlining federal health care programs: Medicare, Medicaid, and tax subsidies for employment-based insurance. ${ }^{226} \mathrm{He}$ also outlines the three major problems health care reform should address comprehensively: "access, cost, and quality."227 Rather than unabashedly touting universal health care, a concept politically unappetizing to most Americans, ${ }^{228}$ Professor Jost instead offers a five-tier private-public partnership placing the highest risk health care with the federal government, the lowest risk health care with individuals, and still offering a safety net to those with the lowest incomes. ${ }^{229}$

Professor Jost places long-term care alongside prohibitively expensive medical procedures and suggests it "should be financed by the government." "230 He would also offer "a basic set of preventive services ... to all regardless of ability to pay."231 "[L]ow-cost, predictable items and services" would remain private responsibilities for "all but the poorest individuals," and "life-style care" would primarily be privately financed. ${ }^{232}$ All other medical expenses "would be covered by insurance" which "[e]veryone would be required by law to carry."233

This type of program is attractive because of the guarantee it would give individuals with disabilities to non-discriminatory health care services. It would also decrease the complexity of the service-provision system for individuals in need of long-term care. However, any attempt to overhaul Medicaid needs to include mandatory, rather than precatory, language about the rights of individuals eligible for the program. Finally, Professor Jost's proposal requires reviews of the tax code and Medicare - topics arguably as unappealing to Congress as Medicaidand as such are likely to meet with the continued incremental approach each topic has faced, not a sweeping overhaul.

\section{Creative Thinking with an Eye Toward Individual Rights}

In the current political environment, many and varied ideas exist as to how to control the cost of health care. Rather than continuing

\footnotetext{
226. Jost, supra note 222, at 557-61.

227. Id. at 573 .

228. See id. at 598 (noting that Americans are "particularly unlikely to accept government provision of health care").

229. Id. at 598-601.

230. Id. at 599 .

231. Id. at 601 .

232. Id. at $599-600$.

233. Id. at 601 .
} 
Medicaid's devolution, completely overhauling Medicaid offers more protection for individual rights. Perhaps Americans are not ready to view health care as a universal, human right. However, when health care is so intertwined with daily life - such as whether a person resides in a nursing home or has a right to receive health care in their own homeindividual rights cannot be ignored.

If legislation today could enjoy the ease of passage the ADA received in 1990, Congress might be able to solve the present dilemma. Congress could amend the Medicaid Act to require reasonably prompt access to waiver services, not just the payment of those services once a waiver slot is available. Congress could clarify the ADA's prohibition against discrimination by public entities to discuss this provision's impact on public health care programs, like Medicaid.

\section{CONCLUSION}

For most people, civil rights - the right to vote, the right to due process, the right to freedom from religious, gender-based, racial, and age-based discrimination - are considered individual rights. However, after recognizing institutionalization as a form of discrimination faced primarily by people with disabilities, the courts and Congress have allowed institutionalization's continued existence. Until Congress introduces entitlement language into the waiver programs, or until the courts enforce the ADA more strictly and without caveats, a freedom from institutionalization cannot be guaranteed for people with disabilities while receiving adequate health care.

Traditional $\S 1983$ litigation no longer offers the same enforcement of access to the Medicaid entitlement due, in part, to the cost-saving mechanisms of the Medicaid Act. The ADA, though prohibiting discrimination in the administration of public programs, has not been able to offer freedom from discrimination (in the form of institutionalization) due to the systemic-basis language of Olmstead. When analyzed together, courts attempting to "navigate ... the murky waters between two statutory bodies: Medicaid and the Americans with Disabilities Act" ${ }^{234}$ have received no assistance from the Supreme Court.

Granting certiorari to a $\S 1983$ Medicaid case could potentially assist lower courts, but it could also amplify the Olmstead problem. Olmstead was decided outside of the Medicaid framework and solely on ADA grounds. If a similar case is decided solely on Medicaid grounds and 
outside an ADA framework, it seems plausible that the two decisions could conflict in application, much like the conflicting applications of the individual statutes.

While attempting to resolve this problem in the existing legal landscape is not an easy task, advocates cannot focus their attention in only one arena. Additional attention must be paid to the devolution of Medicaid and to the additional consequences from the passage of the Deficit Reduction Act of 2005 and the implementation of Money Follows the Person. Will we continue to see an erosion of civil rights for people with disabilities? Can we really start all over with public health care?

Remember Jane's dilemma: she could, with reasonable support, live on her own outside of an institution. It is more cost-effective for her state, as well as more desirable for Jane. Yet Jane is only guaranteed institutional care at this time despite the widespread movement toward community-based services. Jane's individual right has been limited by the interpretation of the ADA's anti-discrimination mandates, and further constrained by Medicaid's devolution to the states.

Laws do not operate in a vacuum. People with disabilities should be able to realize and enforce their civil rights, which were finally recognized with the passage of the Americans with Disabilities Act. More importantly, people with disabilities should no longer have to face the threat of institutionalization as the only guaranteed means to receive adequate health care from a public program. The "serious and pervasive social problem" of discriminating against people with disabilities through segregation and isolation ${ }^{235}$ must end. 